\title{
Ceremonial Entries and the Confirmation of Urban Privileges in France, c. 1350-1550
}

\author{
Neil Murphy
}

In late November 1465, Charles of France arrived at the monastery of SaintCatherine, situated at the summit of a hill overlooking Rouen. He was due to make his ceremonial entry into the town on St. Catherine's Day (25 November), where he was to be formally installed as the new duke of Normandy. Charles's appointment to this position came as a result of his participation in the princely rebellion against his brother, King Louis XI, known as the War of the Public Weal. In the summer of 1465 , Charles had joined a coalition of princes led by Charles the Bold and Francis, duke of Brittany, who forced the king to make major territorial concessions to the princes. Francis dominated Charles, using him as a pawn to increase his own power. Charles's appointment as duke of Normandy was largely due to the actions of Francis, who wanted a pliable duke in control of the strategically important duchy of Normandy. However, as Francis waited with Charles for the townspeople of Rouen to prepare the ceremonial reception, he began to fear that Charles's installation as duke of Normandy would weaken Francis's control over the prince, and thus Francis planned to escort Charles into Brittany before he could make his public entry into the town.

Thomas Basin, then bishop of the neighbouring town of Lisieux, writes that on the afternoon of 25 November Rouen's town council received word from John of Lorraine, count of Harcourt, regarding Francis's intention to prevent Charles from making his inaugural entry into the town. ${ }^{1}$ The renewal of Rouen's rights and liberties were dependent on Charles formally entering the town and confirming these grants as part of an entry ceremony. ${ }^{2}$ In a bid to increase its power over the surrounding countryside, Rouen's town council had opened their gates to League forces in October 1465 , forcing Louis XI to separate Normandy from the French crown. As a result of this action, the

1 T. Basin, Histoire de Louis XI, C. Samaran, ed., 3 vols. (Paris, 1963-72), i. 235-41; P. de Commynes, Mémoires, J. Blanchard, ed., 2 vols. (Paris, 2007), i. 80-81; J. Duclercq, Mémoires, J.A. Buchon, ed. (Paris, 1827) 85-87; Journal de Jean de Roye: connu sous le nom de Chronique scandaleuse, 1460-1483, B. de Mandrot, ed., 2 vols. (Paris, 1894-96), i. 141-42.

2 For the text of the oaths taken at Rouen see: A. Chéruel, Histoire de Rouen pendant l'époque communale 1150-1382. 2 vols. (Rouen, 1843), ii. 7-8. 
success and prosperity of Rouen were dependent on Charles of France confirming the town's privileges and taking up the position of duke. On the evening of 25 November, Rouen's town council sent a troop of armed bourgeois, accompanied by John of Lorraine, to the monastery to compel Charles to participate in the ceremonial entry. Francis, unable to prevent the townspeople from reaching Charles, fled the monastery for the safety of Brittany. The armed townspeople hastily bundled Charles onto a horse with no saddle and, without permitting him to change into ceremonial clothing, led the new duke down the hill to make his inaugural entry. Charles passed through the main gate and was led along the customary processional route in the glare of torchlight until he reached the cathedral, where a service was held before he was escorted to his lodgings. The ceremonies were completed the following day when he was formally installed as duke of Normandy in the cathedral, during which he confirmed the liberties and privileges of both town and duchy. The actions of Rouen's townspeople on this occasion were unusual, and while they may have been prepared to force a weak and ineffectual prince like Charles to make a ceremonial entry, it is highly unlikely that they would have led the French king to enter the town at the end of pike. However, exceptional this event may have been, it does vividly demonstrate that entry ceremonies, providing the moment at which a town had its rights, liberties, and customs confirmed, were important legal events for the urban populations of later medieval and Renaissance France.

\section{Oath-Taking and Ceremonial Entries}

Between the mid-fourteenth and mid-sixteenth centuries the French ceremonial entry underwent significant change, as new elements, such as dramatic performances, were added to the basic processional structure to transform it into a lavish feast for all the senses. ${ }^{3}$ Rituals are distinct from ceremonies in

3 For the development of the French ceremonial entry during this period see: L. Bryant, The King and the City in the Parisian Royal Entry Ceremony: Politics, Ritual, and Art in the Renaissance (Geneva, 1986); J. Chartrou, Les Entrées solenelles et triomphales à la renaissance, 1484-1551 (Paris, 1928); G. Kipling, Enter the King: Theater, Art, and Liturgy in the Medieval Civic Triumph (Oxford, 1998); P. Lardellier, Les miroirs du paon: rites et rhétoriques politiques dans la France de l'ancien régime (Paris, 2003); N. Murphy, 'Receiving Royals in Later Medieval and Renaissance France: Ceremonial Entries into Northern French Towns, c.1350-1570', (Ph.D dissertation, University of Glasgow, 2009); M. Wintroub, A Savage Mirror: Power, Identity and Knowledge in Early Modern France (Stanford, 2006). 
that they effect a change or transformation, and the incorporation of the oathtaking element within the structure of an entry transformed it into a ceremony with a ritual at its centre. ${ }^{4}$ Although the theatre, decorations, and display all had important roles to play in the entry, it was the swearing of oaths and confirmation of urban privileges that had a lasting effect. Following the death or removal from power of a town's ruler, there was a period of instability where the bond between the two was broken. This bond was restored during an entry ceremony, when the ruler swore to uphold urban rights, liberties, and customs in return for the mayor swearing loyalty on behalf of the townspeople. ${ }^{5}$ The precise nature and extent of the rights confirmed at an entry varied from town to town, with the oaths taken designed to include the full range of grants and franchises amassed by the town over time. For example, the text of the oath sworn at Dijon confirmed the libertéz, franchises, immunitéz, chartres et privilèges et confirmations' of the town contained in the 'lettres, ès chartres, données de nos devanciers ès habitans de notre dicte ville de Dijon.' ${ }^{6}$

Confirmation of urban rights and liberties was embedded within a ceremonial entry in some Flemish towns from the twelfth century. When King Louis VI of France entered Bruges with William of Normandy, count of Flanders, in 1127, he swore to uphold the rights and liberties of the townspeople. ${ }^{7}$ As French monarchs claimed to be the feudal overlord of the count of Flanders, this act permitted the king to give a demonstration of his authority over the county, and it is the earliest example I have found of a French monarch confirming urban privileges during a ceremonial entry. The swearing of oaths was not unique to Bruges, and other towns, such as Arras and Saint-Omer, lying within the urban belt which extended across northern France and Flanders, also had

4 See Catherine Bell, Ritual Theory, Ritual Practice (New York and Oxford, 1992), especially 69-93.

5 J.D. Hurlbut, 'The Duke's First Entry: Burgundian Inauguration and Gift', in K. Ashley and W. Hüsken, ed., Moving Subjects: Processional Performance in the Middle Ages and the Renaissance (Amsterdam, 2001), 157-61.

6 '... liberties, freedoms, immunities, charters and privileges and confirmations [of the town council contained in the] letters, and charters, given by our predecessors to the inhabitants of our said town of Dijon'. For the full text of this oath see: T. Dutour, Une société de l'honneur. Les notables et leur monde à Dijon à la fin du Moyen Age (Paris, 1998), 108.

7 J.B. Ross, ed., The Murder of Charles the Good, Count of Flanders, by Galbert de Bruges (New York, 1960), 227. See also: A. Brown, 'Civic Ritual: Bruges and the Counts of Flanders in the Later Middle Ages', English Historical Review 112, no. 446 (April, 1997), 296; J.M. Murray, 'The Liturgy of the Count's Advent in Bruges, from Galbert to Van Eyck', in B.A. Hanawalt and K.L. Reyerson, ed., City and Spectacle in Medieval Europe (London, 1994), 137-52. 
their privileges confirmed at a ceremonial entry from the twelfth century. ${ }^{8} \mathrm{This}$ custom spread from the north-east of the kingdom during the thirteenth century. It was first used at La Rochelle in 1224, while the text of the oath sworn by John II at his entry into Châlons-sur-Saone in 1362 suggests that the swearing of oaths to uphold communal liberties as part of an entry was already a wellestablished custom in the town by this date. ${ }^{9}$ It was during the later fourteenth century, however, that the ceremonial entry came to be the principal occasion on which urban rights and liberties were confirmed. This reflects the expansion in urban government taking place during this period. ${ }^{10}$ Oaths were first incorporated into Parisian entries for John II's post-coronation entry in 1350, though in contrast to other French towns, where the king was asked to uphold municipal liberties, the oath taken at Paris was initially ecclesiastical, with the king promising to defend the privileges of the church and to protect the clergy from oppression. ${ }^{11}$ The scope of the oath taken at Paris was expanded during the fifteenth century, and by the time of Charles VII's entry in 1437, the Parisians, at least, considered the oath taken by the king to be a wider confirmation of rights and liberties. ${ }^{12}$

The form of the oath at Paris was largely set by the time of Louis XII's entry into the capital in 1498 . Once he had sworn to defend the church and maintain its liberties, he 'entretiendroit les nobles, aussi les laboureurs, ensemble les marchans en leurs bonnes loix et coustumes anciennes. ${ }^{13}$ In this way, the king swore to protect all his subjects alike, both noble and commoner, townsperson and country dweller, religious and secular.

8 M. Populer, 'Les entrées inaugurals des princes dans les villes. Usage et signification. L'exemple des trois comtés de Hainaut, Hollande et Zélande entre 1417 et 1433', Revue du Nord 76, no. 304 (1994), 29-30.

9 D. Rivaud, 'Laccueil des souverains par les corps de villes les entrées royals dans les "bonnes villes" du centre-ouest (XV'-XVIe siècles)', in R. Favreau, R. Rech and Y.-J. Riou, ed., Bonnes villes du Poitou et Charentais (XII $-X V I I I^{e}$ siècles): actes du colloque tenu à Saint-Jean-d'Angely (Poitiers, 2002), 273; B. Guenée, and F. Lehoux, ed., Les entrées royales françaises de 1328 à 1515 (Paris, 1968), 141.

10 G. Small, Later Medieval France (Basingstoke, 2009), 158.

$11 \mathrm{~B}$ [ibliothèque] $\mathrm{n}$ [ationale] de $\mathrm{F}$ [rance] Collection Français 23934, fol. 1; Guenée and Lehoux, Entrées royales françaises, $5^{0-51}$.

12 L. Bryant, 'The Medieval Entry Ceremony at Paris', in J. Bak, ed., Coronations: Medieval and Early Modern Monarchic Ritual (Oxford, 1990), 56.

13 '... maintained the nobles, [and] also the labourers, together with the merchants in their good laws and ancient customs ...': Guenée and Lehoux, Entrées royales françaises, 134. 


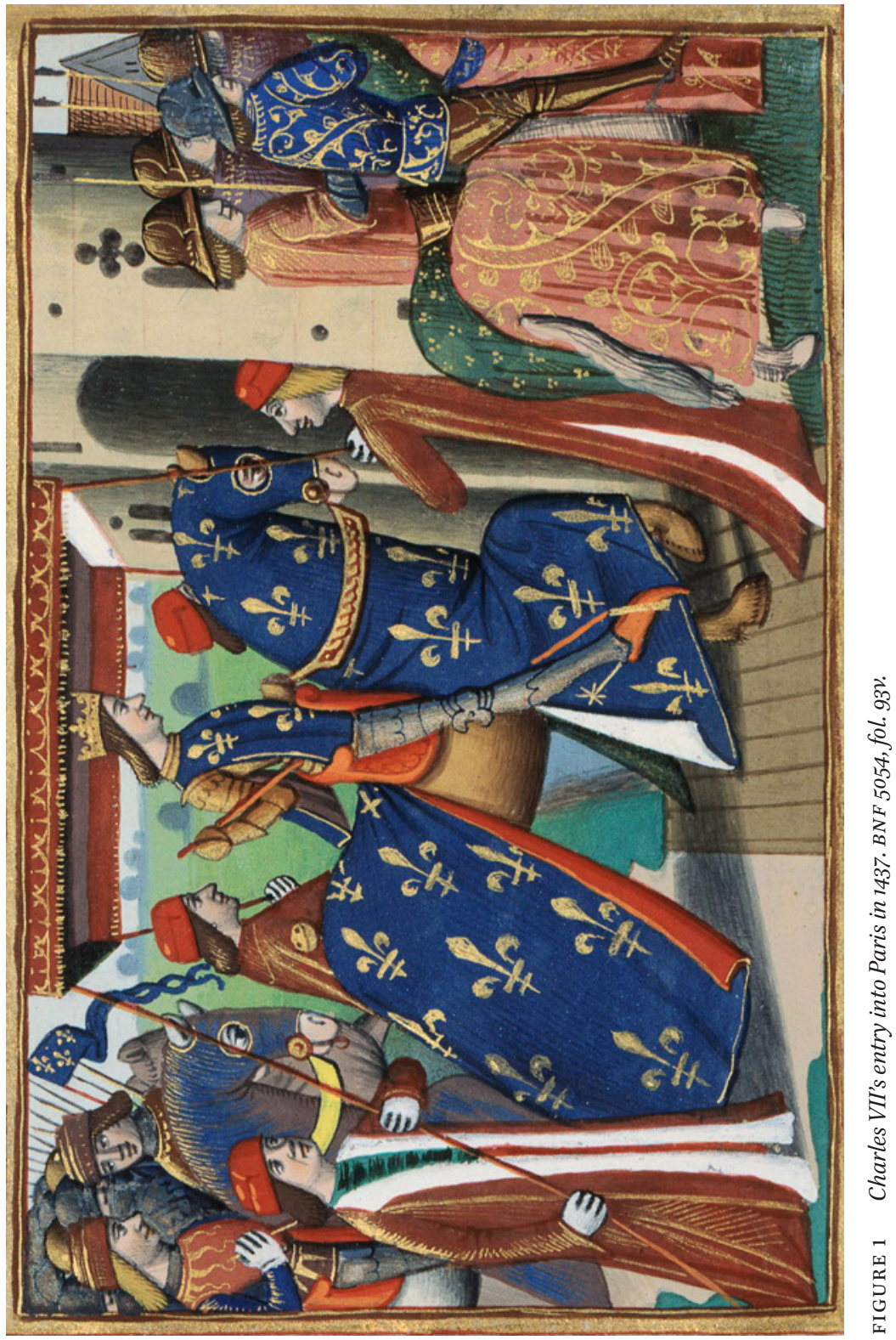




\section{Political Authority and the Confirmation of Privileges}

During the later Middle Ages, both kings and dukes swore to confirm privileges at their entries. The ability to take an oath was a mark of authority, and French dukes competed with the king to confirm privileges at their entries. When the duke of Brittany made his pre-coronation entry into Rennes, he took oaths to defend both the church and people of the duchy as part of a ceremony that imitated the French king's post-coronation entry into Paris. ${ }^{14}$ The confirmation of urban privileges also figured prominently in the entries made by the dukes of Burgundy, who ruled over a patchwork of territories, including a number of important towns in the Low Countries. In these territories, ceremonial entries functioned as 'local inaugurations' for the duke, who received oaths of loyalty from the townspeople recognising his right to rule. ${ }^{15}$ While the duke of Burgundy could claim to be the principal political power in his lands in the Low Countries, the situation was more complex in France. Although Burgundian dukes could and did confirm the privileges in their territories in the kingdom of France, the rights and customs of towns such as Dijon and Arras were ultimately dependent on the authority of the French king. During the weak monarchy of Charles VI some towns in Burgundian France had dared to close their gates to the king, but with the resurgence of royal power under Charles VII and Louis XI in the fifteenth century, French monarchs used the confirmation of liberties, especially those regarding the issuing of pardons, as a means to assert power over often hostile urban populations. ${ }^{16}$

The pardoning of criminals was a regular feature of royal and princely entries in later medieval and Renaissance France. In the thirteenth and fourteenth centuries many French towns had obtained the right to have those people guilty of serious crimes exempted from receiving pardons at a ceremonial entry. While French monarchs tended to respect municipal privileges in this

14 M. Jones, 'The ritual and significance of the ducal civic entries in late medieval Brittany', Journal of Medieval History 29, no. 4 (December, 2003), 289.

15 For Peter Arnade the form of the oath ceremony taken at Ghent was a demonstration of the city's 'power to actualize the count's new rule only upon recognition of the city's legal rights': P. Arnade, Realms of Ritual: Burgundian Ceremony and Civic Life in Late Medieval Ghent (Ithaca, 1996), 30. For texts of the oaths sworn by dukes of Burgundy at their entries into their towns in the Low Countries see: Hurlbut, 'Duke's First Entry', 169-70; E. Lecuppre-Desjardin, Les villes des cérémonies: essai sur la communication politique dans les anciens Pays-Bas bourguignons (Turnhout, 2004), 142-44.

16 When Charles VI pursued John the Fearless across northern France in 1414, towns such as Soissons and Bapaume closed their gates to the French king: R.C. Famiglietti, Royal Intrigue: Crisis at the Court of Charles VI, 1392-1420 (New York, 1986), 140-48. 
matter, pardons could be a source of tension when there was a bad relationship between a king and a town. In the mid-thirteenth century, the town of Arras, which lay in the north-east of the kingdom, received the right to have only criminals guilty of minor crimes pardoned during a ceremonial entry. ${ }^{17}$ Although dukes of Burgundy had upheld this right, the pro-Burgundian citizens of Arras had a fractious relationship with Louis XI, and they were not certain that the French king would honour the town's liberties regarding the banished when he entered in January 1464. Shortly after the news began to circulate that Louis intended to enter Arras, the municipal council learned that many of the banished were gathering at the edge of the town's jurisdiction in the hope of receiving the king's pardon. The échevins sent a letter to the duke of Burgundy, Philip the Good, in which they asked him to appeal to Louis to uphold the town's liberties regarding the pardoning of criminals at his entry. ${ }^{18}$ Louis refused to give a definite answer to both town and duke, saying that he intended to examine the matter with his council. When he arrived at Arras, Louis delayed making his entry into the town for two days, while he examined the town's privileges with his council. It was only when the ruling administration of Arras presented him with the keys of the city on the morning of the entry that Louis informed them that he would respect their rights and confirm the town's privileges at his entry. By means of this act Louis could demonstrate that while Arras lay within the Burgundian dominions, it was a French town and their rights and liberties were dependent on his good favour. Two years later, Louis gave the population of Arras a demonstration of the consequences of losing his good favour. Following the death of Charles the Bold, duke of Burgundy, in 1477, Arras rebelled against Louis's rule, thus breaking the oath of loyalty which they had taken to the king at his entry in 1464. Louis retook Arras by siege before making a triumphal entry into the town through a hole that his artillery had blown in the walls. ${ }^{19}$ This was a striking image of royal power triumphing over a rebellious town, and following this entry he expelled the entire population, renamed the city Franchise and attempted to repopulate it with people from across France. ${ }^{20}$

17 'Registre-Mémorial de la ville d'Arras, de 1354 à 1383', Mémoires de l'académie impériale des sciences, lettres et arts d'Arras 3 (1869), 259.

18 Municipal deliberations cited in: A. Proyart, 'Louis XI à Arras', Mémoires de l'académie des sciences, lettres et arts d'Arras 34 (1861), 102.

19 J. Molinet, Chroniques, G. Doutrepoint and O. Jodogne, eds., 3 vols. (Brussels, 1935-37), i. 189 .

20 This project ultimately ended in failure, and in 1482 Louis had to allow the original inhabitants to return: H. Sée, Louis XI et les villes (Paris, 1891), 287-9o. 


\section{The Act of Confirmation}

The confirmation of liberties was the most important element of the entry ceremony for the townspeople. An urban delegation went to meet the dignitary and discuss the town's privileges in advance of the entry, so that any problems could be worked out beforehand. Prior to the entry of Louis of Male, count of Artois, into Arras in 1382, the town council sent a delegation to his castle at Avesnes, where they explained to the count that it was customary to swear the oath to the commune before entering the town. They informed Louis that the entry gate would remain closed until he had made this public confirmation of their rights and liberties and asked that he not take offence at this. ${ }^{21}$ Some towns placed an obstacle along the processional route, which was removed only after the oath confirming urban liberties had been taken. At La Rochelle a silk ribbon was placed across the king's path, though at other towns the barrier could be more substantial. ${ }^{22}$ When the king made his post-coronation entry into Paris, he was given the text of the oath before he entered the city. As the monarch approached Notre-Dame, the doors were closed before him and opened again only after he had sworn the oath in front of the bishop of Paris. ${ }^{23}$

Pre-entry discussions were an effective means of resolving points of contention, and I have found no instance of a French king or prince refusing to confirm municipal liberties at an entry. However, disputes could arise in those towns where bishops were required to swear to uphold municipal liberties at their inaugural entries. The taking of oaths to respect urban privileges was important in towns such as Beauvais where the bishop possessed extensive territorial and judicial rights. Beauvais had a long history of conflict between the municipal council and the bishop regarding the extent of the rights held by each. ${ }^{24}$ In a bid to have their authority and liberties recognised, the town council had the incumbent bishop swear to uphold municipal rights before permitting him entry to the town. When Odet de Coligny, new bishop of Beauvais, entered the town in 1536 he came to a barrier blocking the processional route, where he was met by the municipal council. He raised his hand and

21 'Registre-Mémorial d'Arras', 259-6o. For the text of the oath taken at Arras see: E. Lecesne, Histoire d'Arras depuis les temps plus recules jusqu'en 1789, 2 vols. (Arras, 1880), i. 226.

22 Rivaud, 'Accueil des souverains', 273.

23 BnF Collection Français 23934, fol. 1; T. Basin, Histoire des regnès de Charles VII et de Louis XI, J. Quicherat, ed., 4 vols. (Paris, 1855-59), ii. 15-16; Entrées royales françaises, 50-51; C. Couderc, 'L'Entrée solennelle de Louis XI à Paris', Mémoires de la société de l'histoire de Paris et l'Ile-de-France 23 (1896), 129, 139.

C. Fauqueux, Beauvais son histoire (des origines à nos jours) (Beauvais, 1939), 23-24, 30-32. 
swore to uphold the 'droits, prumineneurs, prerogatives et privileges donnés par les rois de france aux maire, manans et habitans dicelle ville..25 After the oath taking, the barrier was removed, and the new bishop was able to enter the town. Should the bishop fail to the take the oath, the ceremony was aborted. When Gilles de Luxembourg came to Châlons-en-Champagne as new bishop on 24 January 1504, he was met in an extramural greeting by the municipal council, who stood in front of a wooden barrier which had been placed across the processional route. ${ }^{26}$ The bishop told the échevins that he wanted a canopy to be raised above him during the entry, but they refused to do so as this was a mark of honour reserved for the king alone. Gilles then refused to take the customary oath to the town and the ceremony stopped, leading to a period of ill-feeling between the bishop and the municipal council. ${ }^{27}$

The customary location for the reconfirmation of urban liberties was directly outside the entry gate. ${ }^{28}$ When Charles the Bold, duke of Burgundy, entered Abbeville in 1466 he was met outside the entry gate by the town council who requested him to 'entretenir la ville et les subgetz en leurs drois, franchises et libertez'. ${ }^{29}$ Charles took the oath before entering the town, swearing to confirm the townspeople in 'tous leurs droits, usages, franchises et libertes ainsy que ses predecesseurs ... avoient fait. ${ }^{30}$ Gates were symbolic of urban liberties and featured prominently on municipal seals. During an entry, these structures were ornately decorated and covered with civic emblems. When Henry VI entered Paris in December 1431 as king of France, a herald dressed as Fama came out of the gate to greet the king and extol the virtues of the town, while the gate itself was the location for a pageant based around the arms of

25 '... rights, jurisdictions, prerogatives and privileges given by the kings of France to the mayor, residents and inhabitants of this town...: $\mathrm{B}$ [ibliothèque] $\mathrm{M}$ [unicipale] Beauvais, Collection Bucquet aux Cousteaux 57, 559-60; R. Rose, Ville de Beauvais. Inventaire sommaire des archives communales anterièures à 1790 (Beauvais, 1887), 1.

26 P. Pélicier, Ville de Châlons-sur-Marne. Inventaire sommaire des archives communals antérieures à 1790 (Chalons-sur-Marne, 1903), 27; G. Clause and J.-P. Ravaux, Histoire de Châlons-sur-Marne (Roanne-le Coteau, 1983), 130.

27 Pélicier, Inventaire sommaire, Châlons-sur-Marne, 54.

28 J. de Pas, ed., Entrées et receptions de Souverains et Gouverneurs d'Artois à Saint-Omer XVe, $X V I^{e}$ et XVII ${ }^{e}$ siècles (Saint-Omer, 1908), 11.

29 '... maintain the town and subjects in all their rights, customs, freedoms and liberties that his predecessors had made...': A. Ledieu, Ville d'Abbeville. Inventaire sommaire des archives municipales anterièures à 1790 (Abbeville, 1901), 10.

$30 \quad$ '... all their rights, customs, freedoms and liberties in the way that his predecessors had done... .: BnF Collection Picardie 37, p. 289; Ledieu, Inventaire sommaire, Abbeville, 111. 
Paris. ${ }^{31}$ Aside from gates, other emblems of civic power were highlighted during an entry ceremony. Oaths at Arras were taken with a hand held out towards the town hall, while Louis XI swore to confirm the liberties of La Rochelle with his hands clasped round those of the mayor. ${ }^{32}$ If the town hall was the ultimate symbol of urban liberties, the mayor was the individual most strongly invested with municipal power and such gestures reinforced the legitimacy of the town council's rule. ${ }^{33}$ Devotional objects were also used during the swearing of the oath. John II confirmed the liberties of Châlons-sur-Saone with one hand placed on the gospels, while oaths at Saint-Omer were taken on a reliquary containing the relics of the saint after whom the town was named. ${ }^{34}$ Relics were also carried out of the town in the extramural procession by the clergy to create a temporary sacred space outside the gate of entry, where the power of the saints was invoked to bless the oath-taking ceremony.

The creation of a sacred space formed part of the efforts by the town council to raise the value of the bond created between ruler and ruled to that of a sacred oath. It was important for urban populations that bonds established at an entry be permanent. The text of the oath sworn by Louis XI at his entry into La Rochelle in 1472 stated that the townspeople had the right to resist any attempts by the king or his successors to give away possession of the town to another ruler. ${ }^{35}$ Such concerns were especially important to towns lying on the frontiers of the kingdom. Amiens's position on the strategically important river Somme meant that the townspeople had the misfortune of being placed at the centre of the Franco-Burgundian conflicts of the 1460s and 1470s, with the two sides fighting for control of the town. Following a renewal of the conflict between the king and duke, on 4 January 1471 Antoine de Chabannes, the count of Dammartin, arrived at the walls of Amiens at the head of a royal army and ordered the town to surrender. He told the mayor that the town would be destroyed if it refused to admit him. At a hastily convened meeting of the municipal council, the échevins decided to open their gates to the count rather than risk destruction. Dammartin entered Amiens the following day in the

31 La chronique d'Enguerran de Monstrelet, L. Douët-d'Arcq, ed., 6 vols. (Paris, 1857-62), vii, 44; J. de Wavrin, Anchiennes chroniques d'Angleterre, M. Dupont, ed., 3 vols. (Paris, 185863), ii, 5-6; Guenée and Lehoux, Entrées royales françaises, 62.

32 Lecesne, Histoire d'Arras, i, 226.

33 C. Petit-Dutallis, Les communes françaises: Caractères et évolution des origines au XVIII siècle (Paris, 1947), 233.

34 Pas, Entrées et receptions à Saint-Omer, 17; Guenée and Lehoux, Entrées royales françaises, 141-42.

35 Rivaud, 'Accueil des souverains', 273. 
place of the king, receiving the oaths of loyalty from the townspeople and confirming the rights and liberties of the town on the king's behalf. On 27 May 1471 Amiens's municipal council then received a further letter from Louis XI in which the king promised that the town would never be alienated from the crown again. Such assurances were designed to encourage and maintain the loyalty of urban communities, especially those frontier towns such as Amiens which could feel remote and cut-off from the crown. However, seven months after assuring the people of Amiens that they would never be separated from the crown, Louis planned to return the city to the duke of Burgundy ${ }^{36}$ This was disastrous news for the townspeople, as without Charles the Bold's consent they had received an army within their walls and taken oaths of loyalty to the duke's bitter enemy. Urban communities feared Charles because of his proclivity for destroying cities, with his sacking of Dinant in 1466 and Liège in 1468 carrying a loud message about the consequences of resisting his rule. The destruction of Liège and Dinant was well known in towns across the Burgundian dominions through songs and poems written at the time endorsing Charles's destruction of the cities. ${ }^{37}$ In 1471 Amiens's municipal council feared that their town would be destroyed 'comme ilz avoient fait de la ville de Dynant, laquele ils avoient arse en feu et en flambe'. The matter was so serious that the mayor of Amiens, Philippe de Morvilliers, journeyed to the king, who was then at Tours, to plead the town's case to him in person. After hearing his case Louis assured him that he would not permit Amiens to pass back into Burgundian control. ${ }^{38}$

\section{Conflict and Urban Liberties}

Some French towns took advantage of the instability created during periods of conflict to increase their rights and liberties in return for opening their gates and taking oaths of loyalty. England, France, and Burgundy competed for mastery of northern France during the first half of the fifteenth century. The year 1429 marked a shift in the balance of power, and, following the successful raising of

36 A[rchives] M[unicipales] Amiens BB 11, fols. 4-5, 16v, 51. Quote on fol. 16v; Journal de Jean de Roye, i, 254-55.

These poems can be found in L. de Lincy, ed., Chants histroiques et populaires du temps de Charles VII et de Louis XI (Paris, 1857), 116-45. See also: C. Thiry, 'Les poèmes de langue Française relatifs aux sacs de Dinant et de Liège', in Liège et Bourgogne. Actes du colloque tenu à Liège les, 28, 29 et 30 octobre 1968 (Liège, 1972), 101-27.

$38 \quad$ '... as they had done to the town of Dinant, which they had burned in fire and flame...: AM Amiens BB 11, fol. 63 . 
the siege of Orléans, Joan of Arc and Charles VII fought their way across Champagne to have Charles crowned king of France at Reims. One of the first towns to submit to Charles on the campaign was Troyes, where the king's entry in July 1429 led to the redefinition of the town's privileges. ${ }^{39}$ During his stay at Troyes, Charles VII received delegations from the neighbouring towns of Châlons-enChampagne and Reims, who came to offer him the keys to their gates and take oaths of loyalty to the king. As they offered the keys as a sign of submission, the delegates were instructed by their municipal councils to try and persuade the king to travel from Troyes and make entries into both towns and thus provide an opportunity to extend their privileges. ${ }^{40}$ While Reims, Troyes, and Châlons offered their submission to Charles, the échevins of Compiègne initially held back from opening their gates while they successfully negotiated with the king to obtain new rights to levy taxes on wine. ${ }^{41}$ They insisted that Charles confirm both their existing privileges and these new rights before permitting him to enter the town. It was desirable that these liberties be confirmed in advance of an entry, as the municipal council's bargaining position was considerably reduced once the king and his soldiers had entered the town.

As well as leading to an expansion of urban privileges, a ceremonial entry could also be an occasion when municipal liberties were abolished. The late fourteenth century was a period of discord in France, when urban populations often placed themselves in opposition to the crown. Amongst the most serious of these disturbances were the revolts that took place in Rouen and Paris in 1382 in response to Charles VI's levying of new taxes..$^{42}$ The levying of these taxes contravened the municipal charter which Louis X had granted to Rouen

39 G. Small, 'Municipal Registers of Deliberations in the Fourteenth and Fifteenth Centuries: Cross-Channel Observations', in Jean-Philippe Genet and Joseph Ruggiu, ed., Les idées passen-elles la Manche? Savoirs, répresentations pratiques (France-Angleterre, $X^{e}-X X^{e}$ siècles (Paris, 2007), 57. For the town's preparations for this entry see: A. Roserot, 'Les plus ancien registre des délibérations du conseil de ville de Troyes (1429-33)', in A. Roserot, ed., Collections de documents inédits du conseil de la ville de Troye 3 (Troyes, 1886), 233.

C. Petit-Dutaillis, The French Communes in the Middle Ages, trans. Joan Vickers (Oxford, 1978), 141; Chronique d'Enguerran de Monstrelet, iv, 337; Clause and Ravaux, Histoire de Châlons-sur-Marne, 106.

41 H. de Lépinois, 'Notes extraites des archives communales de Compiègne', Bibliotheque de l'Ecole des Chartes 4 (1863), 484; J. Randier, 'Le gouvernement de la "bonne ville" de Compiègne et ses hommes au temps de la reconstruction (1468-1500)', Bulletin de la société historique de Compiègne 38 (2002), 81-82.

S.K. Cohn, Lust for Liberty: The Politics of Social Revolt in Medieval Europe, 1200-1425 (Cambridge, 2006), 82-83; H.S. Miskimin, 'The Last Act of Charles V: The Background of the Revolts of 1382', Speculum 38, no. 3 (July, 1963), 433-42. 
in 1315, and the issue of municipal privileges was at the forefront of the revolt which erupted in late February 1382 when a group of disgruntled townspeople attacked the abbey of St. Ouen, which had amassed a number of economic privileges at the expense of the town..$^{43}$ Resentful of the grants that the crown had made to the abbey, the rioters tore up the privileges of the abbey in front of the abbot and compelled him to make a new charter renouncing these former rights. ${ }^{44}$ As soon as he received word of the events at Rouen, Charles VI left Paris at the head of an army in order to quell the disturbances. Arriving outside Rouen on 28 March, he was met by the municipal council who protested their innocence in the revolt and implored the king to show mercy to the town. Rather than giving definite assurances, the king told the delegation that those who were innocent would receive mercy, while those guilty of participation in the revolt would be punished. On the following day he made his ceremonial entry into Rouen, with the town council coming out to greet him in procession and leading him through the decorated streets which were lined with townspeople calling out 'Noel'. The townspeople presented the king with the customary gifts provided at inaugural entries but rather than make the usual confirmation of municipal privileges, Charles used the occasion to strip Rouen of its right and liberties. The municipal administration was suspended, six of the ringleaders of the revolt executed, and the town placed under the control of a royal officer. ${ }^{45}$ Charles had the gate through which he entered partly demolished and ordered that the communal bells-which had been used to call the population to revolt - be confiscated and placed inside the royal castle in Rouen. Along with gates, bells were symbolic of municipal liberties and the right to possess a municipal bell was granted in a town's charter. Bells were objects of mass communication. They set working hours, sounded the alarm in case of danger, and underpinned urban festivities, including royal entries. ${ }^{46}$

43 M. Wolfe, Walled Towns and the Shaping of France: From the Medieval to the Early Modern Era (Basingstoke, 2009), 61.

44 Cohn, Lust for Liberty, 82-3. This charter is printed in: S.K. Cohn, ed., Popular Protest in Late Medieval Europe: Italy, France and Flanders (Manchester, 2004), 306; Chéruel, Rouen, ii, $544-46$.

45 Chronique des quatre premiers Valois (1327-1393), S. Luce, ed. (Paris, 1863), 300-01; Chronique des règnes de Jean II et Charles V, R. Delachenel, ed., 4 vols. (Paris, 1910-20), iii. 14; Chronique du Religieux de Saint-Denys, M.L. Bellaguet, ed., 6 vols. (Paris, 1839-52), i. 145; Choix de pièces inédits relatives au règne de Charles VI, L. Douët-d'Arcq, ed., 2 vols. (Paris, 1863-1864), i. 31.

46 C. Billen, 'Dire le Bien Commun dans l'espace public. Matérialité épigraphique et monumentale du bien commun dans les villes des Pays-Bas, à la fin du Moyen Age', in E. Lecuppre-Desjardin and A.-L. Van Bruaene, ed., De Bono Communi Descours et pratique 
Bells symbolised the authority of the municipal government to rule, and the absence of the sound itself would have been a lasting reminder for the population of the king's displeasure with the town. ${ }^{47}$

Charles made a similar example out of Paris, which had also rebelled in 1382 and failed to give him adequate support in his campaign against the Flemish. Returning to Paris in January 1383 after his victory over the towns of Flanders at Roosebeke, Charles was met outside the walls by five hundred of the municipal elite, who came seeking mercy from the king. Disregarding their pleas, Charles entered Paris like a military conqueror, wearing armour and riding at the head of his army. Following his ceremonial entry, Charles placed the capital under military occupation, ordered the execution of several bourgeois, and had the gates of the town destroyed. The king then stripped Paris of its privileges and franchises, suppressed the guilds, abolished the municipal government, and placed control of the capital in the hands of the royal prévôt. ${ }^{48}$ Under normal circumstances a royal entry provided a favourable moment of contact between the king and his towns; at Rouen and Paris, however, Charles subverted the purpose of the ceremony. By making it the occasion for the abolition of municipal liberties, Charles could give a nuanced demonstration of royal power. He made it clear to the elites who lay at the forefront of urban society that their power and authority were dependent on him. Should they fail to maintain law and order on his behalf or should they act in opposition to the crown, then they could not expect to have their privileges and position confirmed.

\section{Changing Patterns in the Confirmation of Urban Liberties, 1460-156o}

Between the mid-fourteenth and mid-fifteenth centuries ceremonial entries were the principal occasions during which urban privileges were confirmed. However, in a trend which began during the reign of Louis XI and which

du Bien Commun dans les villes d'Europe (XIIIe au XVIe siècle) (Turnhout, 2010), 78-80; C. Pattart, Les cloches de civiles de Namur, Fosses et Tournai: recherches sur l'histoire de la communication de masse en milieu urbain (Brussels, 1976), 141-44. For the importance of bells to French communities see also: A. Corbin, Village Bells: Sound and Meaning in the Nineteenth-Century French Countryside (London, 1999).

47 The bells were returned to Rouen when Charles VI restored the administration and privileges of the town in 1389: Chéruel, Rouen, ii. 475 .

48 L. Mirot, Les insurrections urbaines au début du règne de Charles VI (1380-1383) (Geneva, 1974), 184-95; J. Favier, Paris au XVe siècle, 1380-1500 (Paris, 1974), 140-41. 
gathered momentum in the sixteenth century, towns moved to have their privileges confirmed at the beginning of a king's reign, rather than waiting until the inaugural entry. The town of Beaune, for example, had its liberties confirmed at an entry right through to the reign of Louis XI, from which point they were confirmed by letters patent at the beginning of a new monarch's rule. ${ }^{49}$ In many respects it was preferable for urban populations to have their liberties confirmed in this way, as there could be a long gap between the ascension of a ruler and his first entry, especially in more remote parts of the kingdom. The opportunity to have urban privileges confirmed at the start of a reign reduced the period of uncertainty following a monarch's death, when the bond between town and crown was broken. There was little negotiation to be done in this part of the confirmation of liberties, as it was just a general renewal of urban rights. Medieval town councils often asked for rights and liberties as they stood at the time of Louis IX to be confirmed. From the later fifteenth century, however, right through to the reign of Henry II and beyond, town councils asked that the king confirm their rights and privileges as they stood during the reign of Louis XI. This would suggest that while Louis XI has often been portrayed as the great destroyer of urban rights and liberties, for municipal elites his reign actually represented the greatest expansion of urban privileges since the reign of Louis IX..$^{50}$

The move by towns to have their privileges confirmed at the beginning of a reign was hastened by the onset of the Italian wars from 1494, when French monarchs tended to go on campaign at the beginning of their reign. Once Henry II came to the throne in 1547 , for example, he delayed making the customary post-coronation entries into northern towns, including Paris, until he had returned from Italy two years later. In spite of these changes, the swearing of an oath to maintain urban privileges remained a prominent feature of an entry ceremony throughout the sixteenth century, with the key difference being that it was a reconfirmation, rather than a confirmation, of urban liberties. When Henry II entered Dijon in 1548, he swore an oath to uphold the municipal liberties that he already confirmed by letters patent following his ascension to the throne in $1547 .{ }^{51}$ Townspeople also insisted that the king's representatives, particularly provincial governors, swear to uphold urban liberties when making their inaugural entries. When Francis, duke of Longueville,

49 AM Beaune, Carton 1, no. 24 (Louis XI), 27 (Charles VIII), 28 (Francis I), 35 (Henry II), 37 (Francis II), 39 (Henry III), 42 (Henry IV).

5o Sée, Louis XI et les villes, passim.

51 M. de Gouvenain, Ville de Dijon. Inventaire sommaire des archives communales antérieures à 1790,5 vols. (Paris, 1867 ), ii. 67. 
entered Amiens in 1541 as governor of Picardy, the municipal council requested that he take an oath to uphold the privileges of the town. ${ }^{52}$ Motivated by the same concerns that had led municipal councils to ask bishops to swear to respect municipals privileges, urban elites were acting to ensure that their liberties were not threatened by the governor, who stood as a potential local rival to their authority.

The trend by towns to have their privileges confirmed at court also reflects the growing power of the French monarchy during the sixteenth century, which led to changes in the form of the royal entry ceremony. Rather than have as the main focus of the entry the king's procession through the town past the townspeople, during the sixteenth century his urban subjects instead filed past the monarch during the extramural greeting. A dais was constructed outside the walls, from where the king could sit in state and watch thousands of townspeople march past him in procession. For Henry II's entry into Paris in 1549, the town council made a wooden stand at the end of the rue Saint-Laurent. In contrast to later medieval monarchs who met the urban delegation on horseback, addressed them in person, and took oaths to maintain the liberties of the town, Henry II sat immobile and silent on this dais and had the chancellor speak on his behalf when the prévôt-des-marchands offered the keys to the town and asked for a confirmation of the city's privileges. ${ }^{53}$

As well as serving as a demonstration of the monarch's power, the public reconfirmation of urban liberties in front of the multitude of townspeople at the extramural greeting enforced the legitimacy of the municipal council's claim to govern the town on the king's behalf.

\section{Gift-Giving and the Winning of New Liberties}

Ceremonial entries were also occasions when towns could win new grants and liberties beyond those confirmed at the beginning of a reign. While the confirmation of existing liberties took place outside the town, the winning of new rights was closely linked with the gift presentation which took place following the public entry. In addition to the basic gifts of food and wine common to all entries, the town also presented a valuable piece of silverware as part of an

52 AM Amiens BB 24, fol. 53. Bayonne also insisted that governors swear to uphold the privileges of the town at their inaugural entry: E. Dularens, Ville de Bayonne. Inventaire sommaire des archives communales antérieures à 1790 (Bayonne, 1894), 15.

53 Registres des délibérations du Bureau de la ville de Paris. Tome troisième, 1539-1552, P. Guérin, ed. (Paris, 1886), 64. 


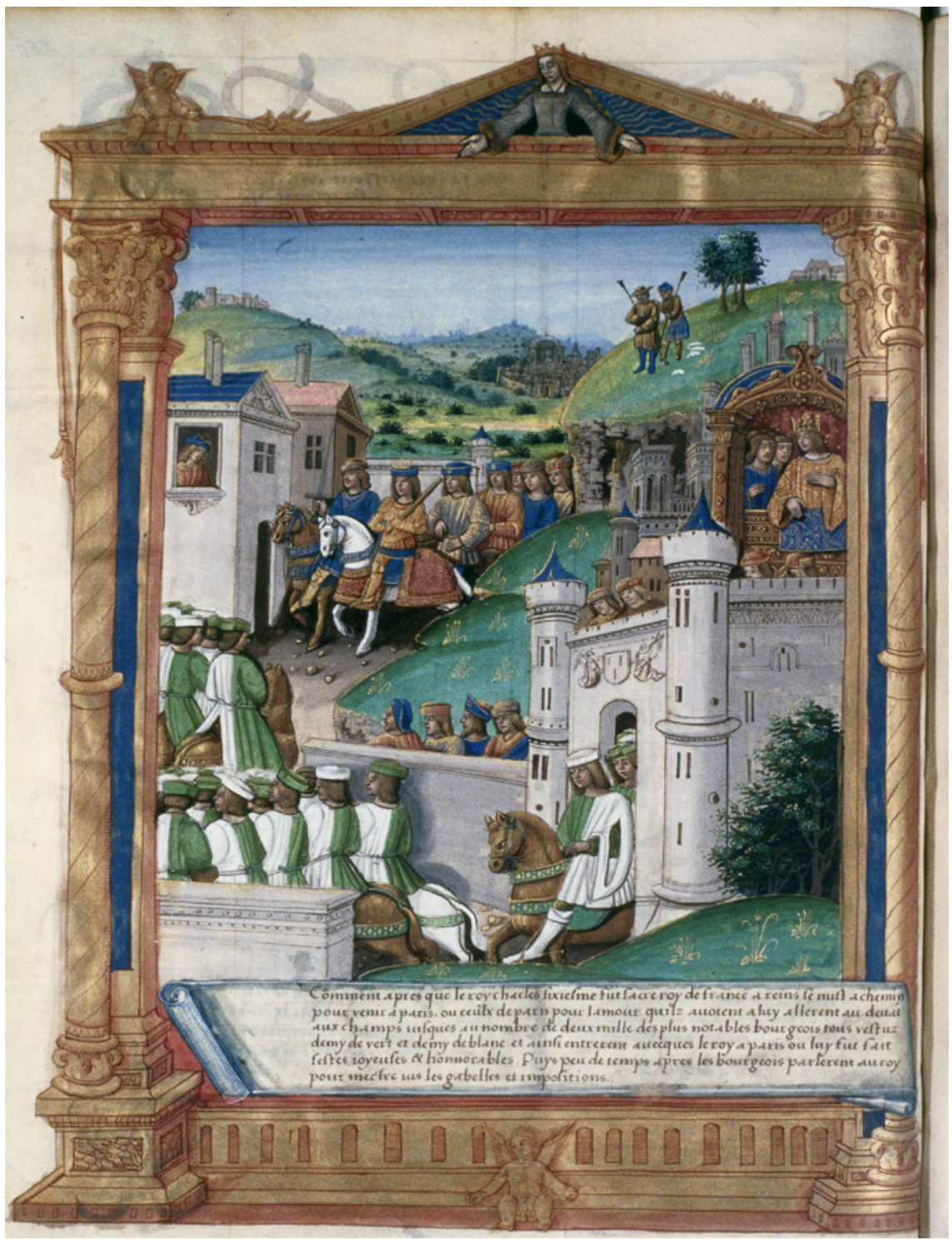

FIGURE 2 Charles VI greeted on horseback by the municipal council at his inaugural entry into Paris in 1380. BNF 138, fol. 260 . 
inaugural entry. This was commonly in the form of a cup or plate, which was engraved with the arms of the town in the hope that it would serve as a future reminder of the town's hospitality.

Amiens's municipal deliberations state that they placed the arms of the town on the silver fountain presented to Anne of Brittany in 1493 'affin que ladite Royne puist, en gardant ladite fontaine, avoir mémore dudit don pour le bien d'icelle ville. ${ }^{54}$ As the design of the gifts became more elaborate from the late fifteenth century, so the costs of commissioning them increased. For Henry II's post-coronation entry into Pairs in 1549 the town council presented a decorative silver statue costing 10,00o l, while the following year Rouen's town council set aside almost 15,000 l. just to buy the presents to be given at the entries of Henry II and Catherine de Medici. ${ }^{55}$ Although gifts could be very expensive, it was hoped that they would serve as a lasting symbol of the town's warm welcome and generosity for many years to come. An entry ceremony was transitory by its nature, but a solid gift of silverware could survive in royal collections for generations and serve as a lasting reminder of the political bond that king and town had entered into during the entry. For Jesse Hurlbut the item of silverware was given in return for the confirmation of the existing rights and privileges of the city and 'in material terms alone, the first entry constituted an exchange that was always to the disadvantage of the city'. ${ }^{56}$ However, while town councils spent large sums of money on these gifts, entries were occasions when towns could win significant new grants and privileges. This result would more than balance out the money spent on the gift, as in order for the king to reaffirm his superiority over the townspeople, he was expected to give gifts of greater value as a demonstration of his wealth and power. ${ }^{57}$

For Pierre Bourdieu it was essential that a time gap exist between the gift and counter-gift as 'the interval had the function of creating a screen between the gift and the counter gift and allowing two perfectly symmetrical acts to appear as unique and unrelated acts. ${ }^{15}$ However, rather than make the two acts appear unconnected, towns in fifteenth- and sixteenth-century France

$54 \quad \therefore$ in order that the said queen could, in keeping the said fountain, have memory of the gift for the good of this town...: AM Amiens BB 16, fol. 234.

55 Registres, Paris (1539-1552), 181; AM Rouen A 16, fol. 119.

56 Hurlbut, 'Burgundian Inauguration and Gift', 173.

57 M. Mauss, The Gift, trans. Ian Cunnison (London, 1954), passim.

58 P. Bourdieu, Practical Reason: On the Theory of Action (Oxford, 1998), 94. For the application of Bourdieu's methodology to gift-giving in entry ceremonies see: M. Damen, 'Princely entries and gift exchange in the Burgundian Low Countries: a crucial link in late medieval culture', Journal of Medieval History 33, no. 3 (September, 2007), 237. 


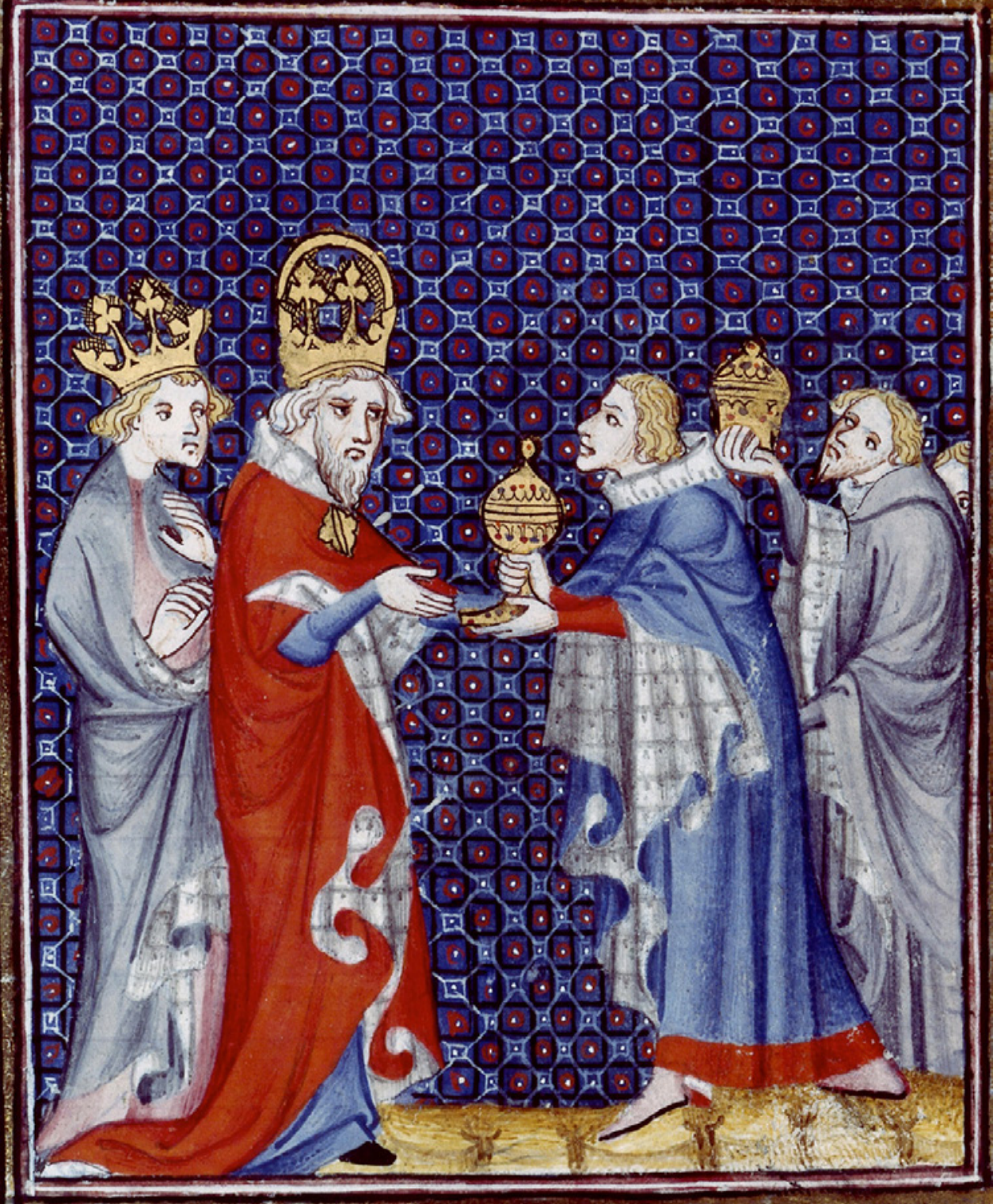

FIGURE 3 The presentation of gifts of silverware to King Charles V of France and the Emperor Charles IV following their joint entry into Paris in 1378. BNF 2812, fol. $478 \mathrm{v}$. 
deliberately timed their requests for further grants to coincide with their presentation of gifts. There was an explicit link between the provision of the gift of silverware and the granting of new liberties to the town. When Louis XII entered Troyes in 1510, the gift of silverware commissioned by the municipal council was not ready in time for his departure. When it was completed they sent deputies to Dijon to present it to the king, and immediately upon receiving the gift Louis granted the people of Troyes their requests made at the entry. ${ }^{59} \mathrm{It}$ is significant that Louis waited until he had received the delayed gifts before making the expected grants, leaving no doubt that there was a direct correlation between the offering of the municipal gift and the counter-gift.

The gift presentation generally took place in the visitor's lodgings after the public entry. It was important that the act itself involve only the king and municipal elite and be hidden away from public gaze, as this allowed for the creation of a more personal relationship with the king in contrast to the distance between the monarch and urban elite in the extramural reception. The gift-giving ceremony provided a point of direct contact when municipal councillors were able to gain an audience with the king, during which they presented him with one or more requests for new grants. While the chancellor spoke on Henry II's behalf at the extramural greeting at his entry into Paris in 1549, the king spoke with the town council himself when he met them in private afterwards to receive their gift and hear requests for new grants. It was very unusual for a king not to grant any of the town council's requests once the gift had been presented, and the échevins had a good chance of winning some major benefits for the town, including the reduction of taxes. The most significant reductions in taxes were often made during inaugural entries, when it was expected that the new monarch would make substantial economic concessions to his bonnes villes. General remissions of taxes were unusual, and it was more common for the town to ask for the abolition of specific taxes or that the profits generated from these taxes be made over to the municipal council. ${ }^{60}$ Grants were commonly made by the king when the money was to be used to maintain the fortifications of the town, especially in frontier regions of the kingdom, such as Picardy and Champagne. ${ }^{61}$ When Charles VIII entered Compiègne in 1486 the

\footnotetext{
59 A. Babeau, Les rois de France à Troyes au seizième siècle (Troyes, 1880), 35.

6o For example, when Francis I and the queen entered Beauvais in 1520, they asked the king to permit them to collect the revenue generated from the sale of salt and fish in the town: BM Beauvais, Coll. Bucquet, vol. 57, 422.

61 For royal grants to fortify bonnes villes see: P. Lardin, 'Le Financement des Fortifications en Normandie Orientale à la Fin du Moyen-Age', in Les Normands et le fisc: XXIXème Congrès des sociétés historiques et archéologiques de Normandie, Elbeuf-sur-Seine, 20-23 octobre
} 
town council successfully petitioned him to collect revenues on certain goods to be used for the fortifications, while Abbeville, situated closer to the frontier, managed to gain the significant economic concession of exemption from paying the taille for ten years following his entry into the town in $1493 .{ }^{62}$

Ceremonial entries not only provided the town council with direct access to the king, they also gave the échevins the opportunity to meet important members of the court and persuade them to support the town in winning grants from the king. In this way the benefits of an entry could pay off for years to come in the winning of new rights and liberties. When the Parisian town council gave Georges d'Amboise wine, spices, and torches at his entry into Paris in 1502, they asked him to 'tousjours lad. ville pour recommandée envers le Roy' ${ }^{63}$ Georges d'Amboise was chancellor of France and one of Louis XII's closest friends, putting him in a good position to influence the king in favour of the town. In their speeches of thanks, dignitaries told municipal councils that they would act on the behalf of the town, thus making an explicit connection between the gift and the winning of friends at court. After receiving the gift from the people of Paris at a banquet held with the town council after her entry, Eleanor of Austria thanked the delegation for the gifts and declared that she would 'faire plaisir à icelle Ville' in the future. ${ }^{64}$ Such declarations were more than just empty rhetoric, as the rules of courtesy dictated that the recipient of a gift had an obligation to return the favour. ${ }^{65}$ When Claude of France, wife of Francis I, entered Arles in 1515, the town council approached her with requests for additional rights. The queen did not have the authority to grant such requests, but as soon as Francis returned from Italy into Provence, Claude told the king of the requests she had received from the townspeople. The king then sent a letter to the municipal council, in which he told the consuls that not only was he confirming their existing privileges, he was also granting them the right to levy taxes on grain sold in the town. Francis explained that these grants

1994 (Elbeuf-sur-Seine, 1996), 47-58; A. Rigaudière, 'Le financement des fortifications urbaines en France du milieu du XIV e siècle à la fin du XV siècle', Revue Historique 273, no. 1 (January, 1985), 19-95.

62 AM Compiègne BB 10, fol. 34v; A. Ledieu, 'Première entrée de Charles VIII à Abbeville (17 juin 1493)', Bulletin Archéologie du Comité des Travaux historique et scientifique 1 (1888), 57.

63 '... always recommend the said town towards the king...': Registres des délibérations $d u$ Bureau de la ville de Paris. Tome Premier, 1499-1526, F. Bonnardot, ed. (Paris, 1883), 67.

64 '... make pleasure to this town...': Ibid., 117.

65 S. Kettering, 'Gift-giving and patronage in early modern France', French History 2 (1988), $146-47$. 
were made 'en faveur du bon recueil et reception qu'ilz ont fait en ladicte ville à ladicte dame la Royne'.66

Demonstrating an awareness of practical politics, municipal councils also targeted the wives of dignitaries at an entry. Tournai lavished gifts upon the wife of the chancellor when Louis XI entered the town in 1463 in the hope of gaining her favour, while the duchess of Longueville was presented with a sculpture of the head of John the Baptist when her husband, then governor of Picardy, entered Amiens in 1541. When this gift was offered to the duchess by the town council she told them: 'emploiez-moi touts pour voz affaires vers Monseigneur, car je suis à vostre commandement' ${ }^{\prime} 7$ Towns competed with each other to win the favour of dignitaries by means of gift presentation. In return for these gifts, the town council hoped that the recipients would act as brokers for the town at court. ${ }^{68}$ When the lieutenant general of Paris, Des Chanetz, described to the Parisian échevins the expensive gift given to Claude of France when she entered Lyon, they worked to outdo their rivals and present the queen with a gift so sumptuous that she would not forget the honneur et don' made by the town. ${ }^{69}$ As well as seeking to gain influence at court in the future, municipal councils also used royal entries as an opportunity to reward members of the court for past efforts in helping them win new grants. ${ }^{70}$ By rewarding their friends at court, municipal councils could hope to maintain the services of a proven advocate for the town.

\section{Negotiations with Royal Officials}

While the presentation of gifts to the king, his wife, and the dignitaries who rode in his entourage was common in the later Middle Ages, the number and lavishness of the gifts provided increased during the second half of the fifteenth century along with the development of the drive towards centralisation taken by the crown against the princely states of France. The provision of gifts

$66 \quad$... in favour of the good reception and welcome that they had made in the said town to the said lady the queen ...: Ordonnances des rois de France. Règne de François Ier, 8 vols. (Paris, 1902), i. 337 .

$67 \quad$ '.. make use of me in all your business towards my lord [the duke], because I am at your command....: AM Amiens BB 40, fol. 23.

68 S. Kettering, 'The Historical Development of Political Clientelism', Journal of Interdisciplinary History 18 (1988), 425-26.

$69 \quad$ '... honour and gift...': Registres, Paris (1499-1526), 238.

70 See, for example, payments made to officials at the entry of Francis I in 1539 for efforts they had made on behalf of the town: AM Amiens BB 23, fol. $3 \mathrm{v}$. 
to royal officers, ministers, parlementaires, and religious figures formed a normal part of the system by which the town won octrois, the remission of a tax, or favours. ${ }^{71}$ As with the provision of presents to other members of the royal family, the impetus behind the offering of gifts to those who accompanied the king was to gain influence with the royal officials who were key in the day-today running of the kingdom. By the sixteenth century, the details of the grants which the town would seek from the king were worked out in negotiations with royal officials before the urban delegation took their requests to the king. As it was customary for the monarch to grant the requests that were made to him following an entry, royal officials preferred to review municipal requests in advance. This was particularly important when the grants sought by the town involved a reduction in royal revenue. It was also essential for the town to have these officials on board. Should the municipal delegation approach the king without consulting the royal officials first, there was a good chance that these officials would obstruct any grants made by the monarch at the entry. While the municipal council of Poitiers was granted a tax remission by Louis XI when he entered the town, their efforts to obtain the money were hindered by royal officials, and they never received the sum due to them. ${ }^{72}$

Members of the royal household sought to exploit the power they had in controlling access to the king in order to extort money from town councils. Prior to Henry II's entry into Amiens in 1558, one of the échevins, Julien Legay, told his fellow members that he had been approached by an official calling himself the 'cappitaine de la porte du Roy', who told him that the municipal councils of all the towns which the king had entered had given him a gift in return for which he had provided access to a private council with the king. ${ }^{73}$ Not wanting to risk losing the chance of winning new grants from the monarch, Amiens's town council ruled that they would provide this gift. The ability to travel with the king greatly benefited members of his household, who received gifts of money from town councils. This custom also increased the prestige of the king, who was seen as a source of wealth and prosperity for those close to him. By the mid-sixteenth century, town councils were expected to provide gifts for a whole range of household officials, with the size and nature of the gift corresponding to an official's position in the household. The king's house-

71 J.P. Leguay, 'Banquets, cadeaux alimentaires et autre présents aux visiteurs de marque dans les villes françaises à la fin du moyen âge', in Jeux, sports et divertissements au moyen âge et à l'âge classique: actes du n6e congrès national des sociétés savantes (Paris, 1993), 197. The continuator of Monstrelet in The chronicles of Enguerrand de Monstrelet, T. Johnes, ed., 12 vols. (London, 1810), x. 373. 
hold had doubled in size between 1480 and 1522 and had over sixty categories of officials. ${ }^{74}$ These gifts were customary, and if they were not given, town councils could find it more difficult to gain access to the king. Gaining access was becoming more restricted by the reign of Henry II. When Henry II came to Rouen in 1550, the town council first approached royal officials seeking to gain access to the monarch. These officials formally introduced the urban delegation to the king, who granted their request to have the royal aides remitted. ${ }^{75}$ Gaining access to the king could be especially important when town councils were competing with other rival urban groups for grants. When Louis XII entered Beauvais in 1514, the abbot of the local monastery of Saint-Pierre won grants that contravened municipal privileges. It was only after being brought into Louis's presence by royal officials that the mayor was able to plead the town's case before the king. ${ }^{76}$

French royal entries have traditionally been seen as an expression of royal power and propaganda over urban populations. In a recent article on French royal entries of the sixteenth century, Robert Knecht writes that they were a 'most effective form of royal propaganda' designed to 'instil into the king's subjects feelings of awe and submissiveness. ${ }^{77}$ In contrast to such top-down studies, this paper has sought to demonstrate that ceremonial entries were cultural encounters between court and city, not courtly ritual forms imposed on urban communities. Although the king or duke provided the focus to the entry, virtually every aspect of the ceremony was controlled and implemented by the citizens of the town, who prepared multifaceted symbolic programmes to promote local concerns to their rulers. The public confirmation of municipal liberties lay at the heart of the programme of the entry. By means of highlighting symbolically important buildings, which were invested with civic power, and creating a sacred space for the swearing of the oaths, municipal councils

74 R.J. Knecht, The French Renaissance Court (London, 2008), 34-35.

75 AM Rouen A 17, fol. 79; AM Rouen A 16, fol. 116.

76 BM Beauvais, Coll. Bucquet, vol. 57, 374 .

77 R.J. Knecht, 'Court Festivals as Political Spectacle: The Example of Sixteenth-Century France', in J.R. Mulryne, Helen Watanabe-O'Kelly, and Margaret Shewring ed., Europa Triumphans: Court and Civic Festivals in Early Modern Europe, 2 vols. (Aldershot, 2004), i. 19, 21. See also: Ralph E. Giesey, 'Models of Rulership in French Royal Ceremonial', in Sean Wilentz ed., Rites of Power: Symbolism, Ritual, and Politics Since the Middle Ages (Philadelphia, 1985), 53. 
sought to ensure that they would achieve a lasting confirmation of urban rights and liberties. While the move to have these liberties confirmed by letter at the beginning of a new monarch's rule was largely complete by the reign of Henry II, French monarchs were still expected to make a public reconfirmation of urban liberties at their inaugural ceremonial entries. Although the central institutions of government came to be permanently located in Paris during this period, the monarchy remained peripatetic right through the sixteenth century. Royal entries were an effective means of closing the distance between the king and the provincial elites, who often had cause to feel cut-off from the administrative centre at Paris. Public ritual was at the very heart of public power in later medieval and Renaissance France, and a ceremonial entry gave a visual confirmation of the legitimacy of the rule of the municipal council. Ceremonial entries were primarily designed and produced by the town council, who negotiated with the king and royal officials to win additional grants following the entry. The ability of urban elites to design and produce impressive civic receptions and obtain new liberties reflects their increasingly important role in the life of the realm during the fifteenth and sixteenth centuries.

Royal entries were not spectacles where urban populations stood speechless in awe of the majesty of French royalty, but occasions when French townspeople participated in a dialogue with the monarch. These negotiations between crown and town reflected the pragmatic workings of the state in latermedieval and early-modern France, which was built on good will and cooperation between the king and local elites by the mid-fifteenth century. Royal entries were not just representations of the theoretical workings of the state; they were the very occasions during which the political bond between the king and his urban subjects was brought into being. A bond implied reciprocal obligations and French legists of the later sixteenth century continued to insist on the maintenance of urban rights and liberties in the face of growing royal power. $^{78}$

78 L. Bryant, 'Parlementaire Political Theory in the Parisian Royal Entry Ceremony', Sixteenth Century Journal 7, no. 1 (April, 1976), 22-23. 